\title{
RUSSIA'S GEOPOLITICAL DETERMINATIONS IN THE BLACK SEA
}

\author{
Ilie-Răsvan DUMITRU, PhD Candidate*
}

\begin{abstract}
The present paper analyzes the projection of Russia's economic and military power in the Black Sea region, seen both in terms of its huge resources and as a way of projecting military power in the coastal States and the Eastern Mediterranean. The energy perspective is important in Russia's geopolitics, and the Black Sea region is perceived by it as the point of confluence of several globalist interests, in which Russia desires not only to be a mediator, but the decisive pivot to impose regional policy. Creating an energy dependency of the West on Russian resources represents a well-defined political goal in the Russian strategy. Russian gas is thus becoming a Trojan horse, by which Russia can influence European policies, this energy instrument being complemented by other powerful instruments aimed at undermining or diminishing NATO's role in Eastern Europe. Russian interests are concentrating firstly on the desire to maintain different levels of political and economic influence in each coastal State, to maintain the Black Sea under control for oil or gas exports and other maritime transport through Novorossiysk port as well as preventing a security deficit toward NATO that could threaten the South-West flank of Kremlin. In pursuing these interests, Russia's strategy is based on the use of political, diplomatic, information and economic instruments, which are supported by an increasingly credible military capacity, analyzed and explained in this paper.
\end{abstract}

Keywords: Russian-Ukrainian war; Crimea; energy weapon; Black Sea.

\section{General observations}

In order to analyze Russia's current conduct, motivation and geopolitical interests, we will take a look at Churchill's speech at Westminster College, Fulton, Missouri of March 5, 1946: "from what I have seen of our Russian friends and allies during the war, I am convinced that there is nothing they admire so much as strength, and there is nothing for which they have less respect than for weakness, especially military weakness"1. Churchill perfectly guessed the specific character of Russian politics, unchanged for centuries, expressing the opinion that Russia does not necessarily desire a war, but warning that Moscow wants the fruits of war and the undetermined expansion of its power and policies ${ }^{2}$.

Russia has the largest territorial surface area $\left(17.125 .191 \mathrm{~km}^{2}\right)$, which stretches from Eastern Europe to North Asia on 17 time zones. European Russia is West of the Ural Mountains, and the Asian side is represented by Siberia, which stretches at East from the mountainous chain to the Bering Sea and the Pacific Ocean. By its size and complexity, Russia has a strong non-harmonious character. Although it covers an eighth of the world's habitable

\footnotetext{
*"Carol I" National Defence University e-mail:dumitrurasvan@yahoo.com
}

land area, it is only the ninth most populated of the world's States. However, even if $75 \%$ of its territory is on the Asian continent, this region is populated with only $22 \%$ of the total population of the state. And although most of the territory is on the Asian continent, Russia having a common border with Kazakhstan, Mongolia, China, North Korea, including the sea border with Japan and the US, it is not an Asian power, but more an European power, given the fact it is an extension of Europe and that the most important part of Russian economic activity is concentrated in the West of the Ural Mountains. Even so, outside the traditional Russian territory established during Ivan the Terrible (15331584), a part of the Russian Federation's population is composed of other nationalities: Ukrainians, Bashkirs, Chuvash people, others. This population heterogeneity required a more strict control regime, situation which can be found including in the existence period of the Soviet Union. But, Siberia represents Russia's resourceful treasure consisting of enormous deposits of ore, oil and gas, meaning that Russia's preferred weapon being the energy one in the current global competition for resources. The projection of Russia's economic power in the Black Sea region, must be seen through its huge resources and less through its economic activity. This fact also gives its regional policy, sometimes aggressive, toward the West, and especially to states 
that are close to its borders. The energy perspective is important in Russia's geopolitics, and the Black Sea region is perceived as the point of confluence of several globalist interests, in which Russia desires not only to be a mediator, but the decisive pivot to impose regional policy. The restrictions imposed by international war laws and at the borders by the North Atlantic Alliance and the Western countries are limiting Russia's ancient right to impose itself militarily, but also economically. This is because the economic dimension of the Federation is not at the level it can impose itself, nor at the level where it can develop as during the cold War. Russia, however, is using energy resources to make them the most effective weapon through which it can impose its regional policy. Creating an energy dependency of the West on Russian resources represents a well-defined political goal in the Russian strategy ${ }^{3}$. Russian gas is thus becoming a Trojan horse, by which Russia can influence European policies, but only the energy resource is not enough to reaffirm Russia as a great regional power, unless it is accompanied by other means of force that undermine or diminish NATO's role in Eastern Europe. Thus, Churchill's vision of Russian politics, although issued at the end of the second world deflagration, is very real in our days.

\section{Short history of Russian state formation}

For Russia, the geostrategic factors of the Black Sea region have not changed since $1853^{4}$, NATO and the United States replacing individual European States as Russia's main geopolitical competitors. In the current regional geopolitical context, Russian gas is the poisoned apple for the West, Crimea being the basis for imposing military force, Turkey representing the pivot, and Turkish straits being the strategic yield. Thus, Moscow's final goal is the access and the military presence in the Eastern Mediterranean, as a counterbalance to the expansion of the US and NATO to the East, as well as an expansion of power in the Aegean sea and central Mediterranean area, to extend the influence on the new road silk created by China that aspires to an universal hegemonic status.

The complex, conflicting, expansive and hostile nature of the Russian Federation could not be understood if we did not enter the sinuous history of this conservative, traditional, rigid and proud people. Russia, as a societal formation, dates back to the 19th century when the Eastern Slavic tribes formed a proto-federation called Kievan Rus, made up of cities around Kiev and those on the Dnieper River, on the current territory of Ukraine. The invasion of the Mongolian in the 13th century, as well as their pressure on Kievan Rus, led to a migration to North-East and a concentration of the Russian ethnic population around Moscow. This concentration of the Russian population led to the formation of Moscow's Grand Duchy. Ivan III the Great (1462-1505) was the one that completed the centralization of the Duchy, by conquering the Russian regions of Novgorod (1478) and Tver (1485). He led a moderate expansion policy, extending the power by unifying the territories inhabited by the Russians, until the Golden Horde ceased to hold the Suzeran feudal power (1480), thus leading to an increase in the force, resources, population and territorial extent of the Duchy. But this territorial expansion had a critical vulnerability, because of the landscapes that did not provide an effective protective barrier against potential invadors, the principality could only be defended by Moscow surrounding forests. The lack of natural obstacles that would allow Russians to organize their defence was the main catalyst for territorial expansion. This policy, based on the idea of attack as a defence, was put into practice by Ivan 4th the Terrible (1533-1584), who claimed the merit of having laid down the foundations of the Tsarist Russia. During Ivan 4th, the Tsarist reached the natural barrier formed by the Ural Mountains in the East, the Caspian Sea in the South and the Arctic Circle in the North. In the next century, the Tsarist extends beyond the natural barrier of the Ural mountains, incorporating all Siberia to the Pacific Ocean of the far East. This territorial expansion allowed the Tsarist Russia to gain strategic depth to which it could turn in case of invasion. Such a large area requires a great logistical effort and a long supply line for the armies, which could exhaust any military force that would desire to take over Moscow. Under the reign of Peter the Great (1682-1725), whose policy led to the emergence of the Russian empire (1721), as well as under the leadership of the Empress Ecaterina the Great (1762-1796), the Tsarist Russia expanded also to West and South, being protected by a huge ring of protection represented by the Arctic region, Baltic region, land of Ukraine, Carpathian mountains, 
Black Sea, The Caucasus Mountains, the Caspian Sea and the Ural Mountains to the Arctic Circle. The endless stretch of Siberia, its poor and cold climate, the desert steppe of North Mongolia, represented a huge natural buffer zone against any attackers; it was the geography that assures the empire that no enemy could attack it from the East.

Russia's extensive geography has presented and presents two large hot regions over which its hostile actors have always created pressure. One is the plain of Northern Europe, which stretches from France to the Ural Mountains, and the second is the Black Sea region. Regarding the Northern Europe plain, it extends from the North-West of France, Belgium, the Netherlands, Northern Germany and all Poland. On the border with Russia, the Northern European plain, which joins with the Russian plain together forming the European plain, is $3200 \mathrm{~km}$ wide and represents a flat region beyond Moscow. It was precisely this flat landscape of this area that allowed large hostile troops to travel around them, relatively easy in terms of mobility, but extremely difficult in relation to large armies supply lines and unpredictable climate. From this plain over the last 500 years, the West has attacked Russia; the first time by Poles ${ }^{5}$, followed by the Swedish army led by Carol $\mathrm{XII}^{6}$, the Napolenian armies ${ }^{7}$, and the Germans in the two world deflagrations. Russia's endless expanse, the supply difficulties of the troops and the capricious climate, determined the French illustrious general A. H. Jomini, who accompanied Napoleon in the 1812 campaign, to leave the legacy of what many armies had to think of: "Russia is a country where you enter easily, but it is very difficult to emerge from"s.

A number of political, economic and military factors have determined Russian leaders to seek and maintain influence in the Black Sea region in order to take control of the region. From the end of the 16th century to the 20th century, the Russian Empire carried 12 wars with the Ottoman Empire $^{9}$, which desired to increase the political and economic influence, especially in the Crimean Peninsula. A permanent base in Crimea would have allowed the control of the Kievan steppes, the Northern Europe plain, the Astrahan region and the Azov Sea. The Black Sea has also been of great interest to Russia, due to the need for military vessels to have access to a hot-water port, which does not freeze in the winter, and which offers free access to major world ${ }^{10}$ trade routes. The port of the Arctic Ocean (Murmansk) and the one of the Pacific Ocean (Vladivosok) are inaccessible for several months a year due to ice, which affects both trade while blocking the Russian fleet to act as a major global naval power. The lack of a hot port to allow free access to the world's oceans has become an important issue, being identified as a strategic vulnerability since Peter the Great period. Forcing access to the Mediterranean and from there to the Pacific Ocean, as well as access to the Indian Ocean through the conquest of Afghan lands, represented vital purposes for Russia's expansionist policy.

During World War II, the Soviets saw Bulgaria, Romania and Ukraine becoming Nazi instruments, through which they tried to defeat the Red Army in southern Russia, in order to take control of oil fields in the Caucasus area.

During this time, the Soviet Union has expanded its influence in the Black Sea region through territorial changes (reannexation of Basarabia $^{11}$ ) and support for the establishment of the communist governments in Bulgaria and Romania, which were forced to align with Moscow's policy. The establishment of the Warsaw Pact in 1955, as a response to the formation of the North Atlantic Treaty Organization, further strengthened the position of the Soviet Union in the region. The Soviet troops, which remained in Romania after 1945 , were withdrawn only in 1958 , but not after they became poor, they robbed resources and led a ferocious policy of economic subjugation of Romania, hidden by the sestablishment of joint companies called SovRoms. During the cold War, the Soviet Union enjoyed a political, military and economic preeminence from Burgas to Batumi. Russia's pressure on Turkey to take control of the straits led to Turkey's adhesion to NATO in 1952. This was compensated by increasing the US ability and of other allied forces to operate from military bases established in Turkey, thus imposing a regional balance of powers that Moscow had to recognize.

\section{Observations on current Russian geopolitics}

Politically, the Soviets perceived the penetration of democratic capitalism in Eastern Europe as an existential threat to the Soviet Union. Its collapse deprived the Russian Federation of much of its influence and regional security around the Black 
Sea. The political loyalty of the former allies at the Black Sea, proved to be fragile with the collapse of the USSR. Although by the Friendship Treaty signed with Ukraine on 31 May 1997, the Russian Federation maintained its Black Sea fleet in the military ports around the Crimean peninsula, the phenomenon of colored revolutions, of roses in Georgia (November 2003), the orange in Ukraine (November 2004) or the failed one in the Republic of Moldavia (April 2009), were perceived as an interference of the West in Russia's geostrategic policy. The full membership in NATO (2004) and the European Union (2007) granted to Bulgaria and Romania (former Warsaw Treaty Member countries), as well as the call of the US President George Bush ${ }^{12}$, urging other NATO leaders to declare that Georgia and Ukraine would join the military alliance ${ }^{13}$, worried the Russian Federation's authorities, feeling obliged to take action. The strong intervention in Georgia ${ }^{14}$ (2008) has significantly damaged Russia's relations with the West and, in particular, with the United States. In fact, at the Munich Security Conference (2007), Putin had warned Western countries about NATO's expansion in the proximity of the Russian Federation ${ }^{15}$, criticizing what he called the US's monopolistic domination in global relations and "the almost constant use of force in international relations". Given the relatively rapid decline of Russian influence in the Black Sea region, Russia was forced to reconsider its role as regional power and to develop a new strategy to protect its interests there, even before 2014. The illegal annexation of Crimea in 2014 forced Kremlin to adopt urgent measures in order to diminish the effects of Western disposed measures.

Given the intensification of the confrontation with the West, which began with the war in Georgia (2008) and escalated with the conflict in Ukraine (2014), it is important to understand how Russia perceives its interests in the region and the strategy it pursues to secure these strategic interests.

When the Soviet Union collapsed, 15 sovereign States were reborn out of the USSR. They can be grouped into 5 geographical regions:

- The Baltic area: Estonia, Latvia, Lithuania;

- The Eastern Europe area: Belarus, Moldavia and Ukraine;

- The South Caucasus area: Georgia, Armenia, Azerbaijan;
- The Central Asia area: Kzahstan, Kirkistan, Tajikistan, Turkmenistan, Uzbekistan;

- The Eurasian area: Russia.

Thus, geography replaced the Soviet ideology, the borders of sovereign States regaining their logicalconfiguration, following the mountain, lakes, rivers and seas line. Traditional borders delimit spaces where peoples speak their own language and respect their traditions stemming from history. The exception is the 'stan' that emerged from the old Persian empire, with the artificially drawn borders by Stalin, which sought to weaken the national power of States by intercalating national minorities in neighboring States.

These states detached from the former USSR can be divided into three categories, depending on Russia's influence on their policy:

- neutral States: Uzbekistan, Azerbaijan and Turkmenistan. They are energy independant and are neither indebted to the West nor to Russia regarding the security and trade, which leads them to reconsider their national policies on their own. In an attempt to reduce neutrality and relative independence, Russia planted frozen ${ }^{16}$ conflicts inside or close to them;

- pro-Russian States: Kazakhstan, Kyrgyzstan, Tajikistan, Belarus and Armenia. All of these States are economically interconnected with Russia, have Russian minorities well integrated into society, are part of the Eurasian Economic Union ${ }^{17}$ (except Tajikistan) and the Collective Security Treaty Organization - $\mathrm{CSTO}^{18}$ (also except for Tajikistan).

- pro-Western States are Ukraine, Georgia and Moldavia, which aspire to join both NATO and the EU but are under Russia's influence, which consider them included in the concept almost abroad, keeping on their territory, through enclaves or autonomous regions, which fuel frozen conflicts, military troops or pro-Russian militia.

In addition, the other States that were part of the Warsaw Pact are all in NATO and the EU ${ }^{19}$, namely: Poland, Latvia, Estonia, Lithuania, Hungary, Romania, Bulgaria, Czech Republic, Slovakia and Albania.

Of all these States, coastal to the Black Sea are all the pro-Western, except for Russia. This explains why Kremlin intervened so brutally in Ukraine's politics, against the background of the political tensions escalation over the direction Ukraine was heading toward in 2013. 
Prior to Georgia conflict (2008), the Black Sea was promoted as a model of naval cooperation between former cold War opponents. Joint naval activities (BlackSeaFor and Black Sea Harmony), as well as Russia's regular participation in NATO's Active Endeavor Operation, promised a future in which all Black Sea coastal States could work together to ensure a regional security climate, reducing threats such as smuggling or human trafficking. This cooperation climate deteriorated after the Russian-Georgian war, but elements were maintained until 2013 as a result of the combined efforts of Russian and NATO members - in particular Turkey. With the annexation of Crimea, the war in Donbas and the sharp degradation of relations with the West, the cooperative element of the Russian military strategy has turned to political and subversive confrontation with NATO as well as competition for military presence in the Black Sea and Eastern Mediterranean regions.

I believe that Russia did not want and does not want a conflict with NATO, but the proximity to its border creates tension and concern to not react, especially as it was advanteged by factors that could allow hybrid aggression to be lightly launched, as: the presence of a significant Russian minority in Crimea and the eastern proximity of Ukraine, a tense and destabilizing climate, a significant military force in the vicinity of the area concerned, as well as a vulnerability of the institutional and administrative framework of the peninsula.

If Ukraine's leadership had been a pro-Russian government or at least a neutral government that did not join Western organizations, Russia would not have acted brutally because it would have been guaranteed to preserve a buffer zone in the Northern Europe plain and the Black Sea, that will protect the Russian Federation from possible aggression. It needed guarantees that the naval base in Sevastopol would not be affected by a pro-Western direction of Ukraine, also relying on the fact that its energy dependence on Russian resources was a solid counterargument that would keep it within the Federation's influence. Ukraine's entry on a proWestern axis was a risk of proximity to Russia, which could have led to the transformation of the Sevastopol base into a NATO military base. The situation has become tense because the Ukrainian President, Viktor Yanukovich made the mistake of running on two fronts, in an attempt to obtain economic and political advantages from both the West and Russia. This game attracted the animosity of the pro-Western population that triggered the EuroMaidan revolution, which finally led to the 2014 event. Yanukovych's dual policy was not unique, as this strategy was also found in Igor Dodon, Vladimir Voronin, Vladimir Plahotniuc, Aleksandr Lukashenko and the Armenian leader Serzh Sargsyan.

The idea of having a common border with a NATO or EU Member State is unacceptable to President Putin's policy. Establishing a NATO military base near a Russian one (Sevastopol) is inconceivable for Russian politics, which sees all this Western expansion as a formal aggression against Russian politics ${ }^{20}$. After the forced annexation of Crimea, no matter how we try to look in another direction, politically and militarily, what is happening in the Black Sea region is pivotal, not only for the States in the neighborhood, but also for the Western Balkans, the Middle East, The Baltic Sea area and even the far North. The strategic importance of the Black Sea is also given by the fact that Sevastopol is the only Russian sea port, with warm water, which greatly increases its economic and military potential. From this military port, Russia can exercise its control over the maritime traffic from the Black Sea region. But access outside this region is not easy. To exit into the Mediterranean is restricted by the 1938 Montreal Convention, which allows Turkey (NATO Member country) to control trafficking on the Bosphorus straits. Military vessels may only transit the area in limited numbers and tonnage and only in peaceful conditions. Even if they manage to pass through the Bosporus, in order to enter the Mediterranean, Russian military vessels should be allowed access to the Aegean Sea. Further, the access to the Atlantic Ocean, from the Mediterranean, can only be achieved by allowing passage through Gibraltar straits. The Indian Ocean can only be allowed to pass through the Suez Canal, under the control of an $\mathrm{MFO}^{21}$ multinational force. Another strategic difficulty is that the Russian fleet in Kaliningrad can only exit the Baltic Sea through the Skagerrak strait, which connects with the North Sea, controlled by Denmark and Norway (both NATO Member States). Even if Russian vessels were able to pass through this narrow corridor for access to the Atlantic Ocean through the North Sea, they 
would have to pass through the corridor defined by Greenland, Iceland and the United Kingdom (GIUK corridor). All these restrictions limit Russia's potential to become a great naval military force and to aspire to a status of world hegemon. In this situation, Russian strategic interests in the Black Sea region are largely focused on security, political and economic influence reflecting the country's high-power status.

Interests of the Russian Federation in the Black Sea. In the field of security, Russian military forces in the region exist to protect critical areas to economic production, to ban illegal activity, to ensure safe navigation and to help carry out foreign policy actions in economically important maritime areas, joint applications or peacekeeping operations ${ }^{22}$. From strategic point of view, Russian forces in the region are intended to secure Russia's South-Western flank from an attack against the state, to intimadate and discourage the neighbors from pursuing policies contrary to Moscow's interests, even by force if necessary. The capacity of these forces to carry out operations in the Black Sea was demonstrated in the Russian attack on Ukrainian navy vessels and the detention of 24 sailors aboard near the Kerch Strait on 25 October $2018^{23}$.

In addition to its security interests, Russia pursues political interests on all coastal States in the Black Sea. Since Bulgaria and Romania are both EU members, and both as well as Turkey, are members of NATO, influencing their policies is more difficult in the post-cold War period. Recent history has shown that Russian political influence in Ukraine and Georgia is more efficient from Moscow's point of view, because they do not belong to Western or North Atlantic structures. The russian policy consists in Moscow's attempt to support those who favor friendly relations with Moscow, together with the rejection of those who do not have a pro-Eurasian policy. Regarding Russia's economic interests, Turkey and Ukraine are Russia's largest trading partners in the region, with a larger trade than the other coastal countries. Thus, Turkey had a total trade volume of $\$ 26$ billion $^{24}$ in 2018 and Ukraine $\$ 11,7$ billion ${ }^{25}$. Russian exports to trading partners are primarily focused on natural resources (mainly natural gas), which is seen as an efficient economic weapon to influence other States' policy. However, it is not only the energy resource that is an instrument for influencing other states, but also other marketed products or even tourism are used to influence the positions of sovereign States. Thus, at the end of 2015, Moscow imposed economic ${ }^{26}$ sanctions consisting in limiting trade in agricultural products and restricting tourism in Turkey, following Ankara's shooting down of the Russian bombers Su-24, which entered into Turkish airspace.

A key element of how Russia perceives its interests in the region and how these interests can be threatened is the nature of Russia's relationship with the West. During the early years of Putin's regime, Kremlin sought to engage in a good cooperation with the United States and its allies. Even after the accession of Bulgaria and Romania to NATO (2004) and the EU (2007), there was a certain degree of security cooperation in the Black Sea region between Russia and the West. Until the deterioration of relations with the West and the United States, especially after the Georgian War (2008), Russia had not clearly defined its security, political and economic interests in the region, balancing between zero-sum or confrontation relations. After the crisis in Ukraine, the sharp deterioration in relations with the West led to a reconsideration of Russia's security policy, with the expansion of the EU and NATO perceived as a threat to the stability of the Russian state ${ }^{27}$. At the same time, Russia's position can be seen as an act of persuasion by displaying a minimum degree of influence that it believes should maintain in its neighborhood, regardless of the state of relations with the West.

Regarding the objectives of the Russian Federation in the Black Sea, the official strategic documents represented by the military doctrines and Russia's national security strategies, do not mention any significant details on the Russian geopolitical direction in the Black Sea region. But its policy can be deducted on the basis of Russian interests and behavior, showing the gap between desire and acceptance, respectively, what Russia would prefer, and what it would accept. Since Vladimir Putin came to lead Russia, it had de facto reprinted the status of great Eurasian power. This hegemonic quality claimed by Russia seems to mean that Russian leaders would prefer to benefit from a privileged influence by establishing a mechanism for the reintegration of the former Soviet republics into Eurasian structures, except for the Baltic 
States (Estonia, Latvia and Lithuania). In the Black Sea region, this reintegration project gives Russia greater security, political and economic influence in Ukraine and Georgia (as well as in Moldavia and Armenia). The final outcome can take a variety of forms, but Russia's main objective remains to maintain influence in Ukraine and Georgia and to prevent, by any means, their integration with Western and North Atlantic structures. Given the deteriorating relations with the West and the United States' reaction after the events of 2008 and 2014, Russia could continue to accept Western-oriented governments in Kiev and Tbilisi, as long as these countries reconsider their position toward NATO or the EU.

Regarding the policy of Bulgaria, Romania and Turkey, which are already integrated into NATO, the prospects of drastically changing its geopolitical orientation are almost null and void, Russia not being willing to pursue this, which does not lead to any results. Russia's policy, however, betrays actions that are likely to undermine or counteract any anti-Russian policies perceived as coming from within the region, supporting any opportunity that promotes Russian interests in the Black Sea region. Kremlin's political goal is to support leaders, particularly in Ankara and Sofia, who stand tolerant for greater engagement with Russia and are willing to act on these inclinations, ideally in ways that resemble division and uncertainty in the West.

In essence, Russia desires that the governing regime in each NATO coastal country to respect Russia's status as a regional power and not to allow the development of a security situation that legitimately threatens its South-West flank. In Russia's opinion, a possible integration of Ukraine, Moldavia or Georgia into NATO and EU structures is seen as a long-term threat, which aims to undermine the Eurasian Economic Union by fueling Western political influence on Russia's borders. The perspective of a such integration would justify the promotion of Russian interests in all key areas that would at least affect the policies of the coastal States. This vision is underlined by Russian military interventions in both countries since 2008.

The Russian Federation strategy at the Black Sea consists in a combination of non-military and military instruments, whose content and application depend on the context and political orientation of each country. Russia's regional policy strategy is adapting to a large extent to key factors such as history, culture, security considerations and currently geopolitical realities. Russia is emphasising on former Soviet republics, which, in addition to being part of "almost abroad" politics, have a significant Russian minority, are contiguous and share a common culture and history. In 2013, Russia made a sustained and targeted effort to discourage Ukraine and Georgia (and Armenia and Moldavia) from signing the association agreements in the Deep and Comprehensive Free Trade Area DCFTA with the EU. These steps led Armenia to unexpectedly abandon the pursuit of an Association Agreement in 2013, joining the Eurasian Economic Union. Russia has probably sought a similar reversal of the Western path in Kiev and Tbilisi, but did not manage to achieve this goal. Putin claimed in a documentary interview in 2015 that the West was deliberately trying to undermine Russia's so-called Eurasian integration efforts ${ }^{28}$. From Georgia's, Moldavia's and Ukraine's point of view, getting closer to the EU, more economically stimulating, was more attractive than joining the relatively poorer Eurasian Economic Union, which Russia sought to dominate for its own interests. In order to change the policies that Moscow considers unsatisfactory, Russia has engaged in a variety of political, informational, economic and clandestine activities in these countries and in other countries in the region. In Bulgaria, for example, Russia used elements of history, culture and religion to support Russian initiatives and to generate dislike to the West $^{29}$. Kremlin also directly threatened the use of force against Romania in 2016 in response to Bucharest's decision to host the US missile defence infrastructure on its territory ${ }^{30}$. For Romania, the risk of hybrid aggression coming from the Russian Federation or its potential economic partners is growing, as there is no Russian or pro-Russian minority on Romanian territory and the fact that the country is in a geographic area in which Russia has the right to express itself. As a matter of fact, Romania is still trapped by the geostrategic decisions taken by the great allied military powers led by Napoleon and Alexandru I of Russia in 1807, through which the influence in Europe was divided. The naughty document ${ }^{31}$, as the percentage agreement is known, that ruled on the understanding between Churchill and Stalin of dividing Eastern 
Europe in spheres of influence, in fact, it was merely a reconfirmation of the agreement in the Tilsit Treaty (1807) between the great Eastern and Western powers of the beginning of the 19th century, which were fighting for supremacy over Europe.

Given the changes in strategic direction in 2014, it is clear that Russia is rebuilding its military capacity around the Black Sea. The plan to reequip the Black Sea fleet and other forces in the Southern military district, however, preceded the annexation of Crimea and the war in Eastern Ukraine. Even if there had been no Euromaidan protest movement in Ukraine, Russia would have delivered modern weapons to its armed forces in relatively large numbers. This is because Russian leaders believe that in all geopolitical circumstances, Russia needs an army that credibly discourages potential foreign aggression and is strong enough to coerce regional actors if necessary. I believe that Russia had a wellestablished security strategy even before the crisis with Ukraine. In particular, the increased capacities for the Southern military district, which was part of the state weapons Program, which started in 2011, would have ensured the exceeding quantity of local soldiers and, to a certain extent, would have served as a discouraging factor against Western intervention in the event of a regional crisis. The strategic discouragement is primarily supported by Russia's strategic nuclear forces (strategic rocket forces, strategic naval forces, strategic aviation and tactical nuclear weapons), while the conventional discouragement against NATO in the Black Sea region could involve increased long-range attack capacity from surface and submarine combatants, $\mathrm{A} 2 / \mathrm{AD}$ assets and other general-purpose forces in the region.

The annexation ofCrimeaand the corresponding deterioration of Russia's relations with Ukraine and the West have changed Russia's plan for its army in two ways. Firstly, the annexation of Crimea allowed the Russian Federation to relocate a considerable amount of military capacity $300 \mathrm{~km}$ West to increase the fleet and naval infantry that were already there. Given the current and likely future state of relations between Russia and the West, this increased capacity allows Moscow to threaten NATO beyond the Russian political center and potential theaters of military operations, such as Ukraine, the South Caucasus and, to a lesser extent, Moldavia. This issue is possible considering the buffer territory with NATO border limit along all axes except the South-East. The other way the plan changed for Russia was to reposition and restructure a relatively large amount of fighting power along many Russian borders with Ukraine. In many respects, this repositioning does not cost Russia much, given that major security threats come today from western Russia, and forces along the border with Ukraine could be moved to the North in case of a crisis there (although perhaps Russia would accept a higher risk in Ukraine or maybe in Georgia, depending on the number of forces that have been redeployed). This statement will remain valid as long as there is no major friction between Russia and China regarding the activities in Central Asia or the far East, which may require Russia to rely on existing forces.

In the event of a crisis triggered elsewhere, the provision of the South-West flank would be more precarious for Russia than for the Soviet Union, which had a much larger human and financial resource at its disposal. The threshold for Russia that employs these new forces on the non-NATO territory adjacent to it is, of course, quite low. Historical evidence, recent Russian behavior and rhetoric suggest that the former Soviet area is essential to Russia's political, economic and security objectives. Russian leaders have explicitly stated on several occasions in their speeches, remarks and official strategic documents that the reintegration of the former Soviet Union States in one form or another is a key political objective ${ }^{32}$. Considering Russia's actions in Ukraine, since 2014 - which, at least to a certain extent, were linked to Russia's attempt to involve Ukraine in the Eurasian integration project - remains unclear Russia's availability to accept that Ukraine (as well as Georgia, Moldavia and Armenia) is outside these processes of Eurasian integration. What seems clear today is that Russia has recognized that some of its neighbors can sign association agreements with the EU. But Moscow will certainly oppose, by non-military as well as military means (excluding on NATO Member States), any formal political or military integration with the West, such as NATO or EU accession.

Historically, the potential loss of an ally, reoriented to the West, represented casus belli for Russia (and the Soviet Union), although this 
did not always lead to military intervention. For example, neither the Rose Revolution in Georgia in 2003 nor the Orange Revolution in Ukraine in 2004 have led to clear military actions by Russia. More recently, the popular revolution in Armenia in 2018 - targeting Serzh Sargsyan, a Kremlin ally, who was outed from power and replaced by the leader of the revolution - did not require a forceful intervention by the Russian army. On the other hand, the Russian war with Georgia in 2008 and the Russian intervention in Crimea and Eastern Ukraine took place in the context of the potential change of direction of these countries. They have become too Western for Russia's protective and expansive taste, although circumstances have been different in each case. In Georgia, Russia deployed troops to strengthen its control of South Ossetia, which the Saakashvili regime is threatening. In Ukraine, Russia sent forces to Crimea only after the Ukrainian President Viktor Yanukovich, who was more friendly to Moscow's politics, fled the country and a pro-Western government was formed, potentially threatening Russian interests, including the navy base in Crimea.

Clearly, the decision to intervene militarily is much more complex than it seems at first sight and may depend on many factors and actions, some of which may not come from Moscow. There are certainly many aspects that are not public, about the decisions of Kremlin in relation to the aforementioned crises. However, it is known that neither the Soviet Union nor the Russian Federation deployed military forces in a NATO country with the intention of taking hold of the territory or of forcibly changing the political status quo. Several times $^{33}$ Moscow has deployed forces in areas of strategic interest only when there was little or no chance of intersecting with NATO forces.

As an exception, Russia's intervention in Syria in 2015 - where US troops were present and there was a declared US policy, however informal, against the continuation of the Assad regime - was, to some extent, a normal aspect. On the other hand, given the small number of US forces present in Syria, Moscow was probably relatively confident that the war with the United States is unlikely. Publicly ${ }^{34}$, Putin suggested that Russia intervened in Syria to prevent the spread of terrorism and to rule out an outcome - the fall of the Syrian government - which resembles with the Western actions in Yugoslavia,
Iraq and Libya ${ }^{35}$. In the light of future large-scale intervention in Ukraine or the South Caucasus, Moscow would probably study the possibility and ability of NATO to respond militarily, in addition to other military ${ }^{36}$ forecasts. In general, a change (or possibility of change) in the political status quo to the detriment of Russian interests and in favour of the West remains a relatively reliable, albeit insufficient, indicator of possible Russian military intervention in the Black Sea region. But this does not exclude Russia from interfering with hybrid means and instruments, below the limit of detection or through third parties, in order to achieve the goals.

\section{Conclusions}

When the Soviet Union collapsed, the Russian Federation inherited considerably less influence in the Black Sea region than its Soviet predecessor had, as well as fewer global resources to mitigate perceived threats. At the same time, recent history has shown that Russian interests in the region have remained largely unchanged, especially as regards the former Soviet republics. This dynamic added a degree of urgency and tension to the region which was probably less intense during the cold War because of Soviet influence in the capitals of coastal States and the larger maritime area controlled by the Russian military fleet.

Russian interests focus primarily on the desire to maintain different levels of political and economic influence in each coastal State, to keep the Black Sea under control for oil or gas exports and other maritime transport through Novorossiysk port, as well as preventing a security deficit toward NATO that could threaten the South-West flank of Kremlin. Russia's strategy to pursue these interests is based on the use of diplomatic, informational, political, cyber and economic instruments, which are supported by an increasingly credible military capacity. Moscow's calculation of the possible use of force in the Black Sea region is shaped by many factors.

Regarding the possible elements or implications of a Western compensatory strategy, there are at least two key aspects of the research contained in this article. Firstly, Russian interests in the region are not the same for all coastal States. Russia's relations with NATO members (Romania, Bulgaria and Turkey) are secondary to its relations with Ukraine 
and Georgia. Considering the future policy toward these latter countries, the United States and NATO must determine their own commitment, tolerance of risk and prioritization of the policy, while taking into account possible Russian reactions. Secondly, although it is not necessarily a hunch of future action, Russian behavior over the past two decades has shown that Russia is not seeking a military confrontation with NATO and willendeavor to avoid any scenario involving a large-scale deployment of its land forces. They are no longer structured to lead a long-term war, on a large scale, or supported by a large economy (as compared to that of the West). A large-scale military intervention in the Black Sea region, although unlikely, cannot be excluded, but Russia's aversion to expose a significant part of its land forces suggests that continuing and persistent demonstrations of NATO cohesion and political resilience in NATO partner countries could be key factors in deterring and coercion of Russians in the region.

Finally, I believe that the Russian position on security suggests three important ways in which Russian leaders look at the Black Sea region and Russia's strategy.

The Black Sea is not a single region important for the security of the Russian Federation, but it has its importance in relation to the confluence of interests between Asia and Europe. About the Russian national security thinking, the Black Sea is a distinct region, but its importance does not prevail over other regions of equal importance, such as the Baltic area. Certainly, the Black Sea has a unique geographical feature, with operation environment implications, including hot water ports. But treating the sea and surrounding nations as a single region risks imposing an inaccurate framework of Russian thinking.

The Black Sea and the coastal States do not occupy a certain discrete space on a general list of Russian regional priorities. More specifically, the area is a crossroad of several of Moscow's main national security concerns, varying in nature and intensity. The most important of these concerns are the places Russia considers to be close to home (almost abroad) and therefore integrated into Russia's own sense of identity and security. These areas include all Ukraine, Moldavia and Georgia, with Russia always launching pretensions on Crimea, Abkhazia and South Ossetia (including over Transnistria), so those territories have a particularly deep resonance for the Russian spirit. Both Ukraine and Georgia as a whole are part of Russia strategy to control as many areas circumscribed to the extent area of the Black sea. Moldavia occupies a special, distinct place, because the launching of some aggresions in the region would involve the crossing of Ukraine, which would expose the Russian forces too much.

In a more practical sense, the Black Sea is important due to the projection of its significant power and access to Russia - in particular, access to global maritime trade and communication routes, opportunities for power projection at strategic distance as well as the expansion of air and coastal defence. The east-west axis crossing the Black Sea from the Caucasus to the Balkans is the strategic trade hub for trade between Asia and Europe.

Also, the reason for Russia's national security concerns is the closeness of NATO forces and its military operations to Russia's proximity areas. In Kremlin's view, the region poses risks to Russia's security. Any challenge for Abkhazia or Crimea or for the rest of Georgia or Ukraine - directly and intimately affects Russia's sense of security. The claim of Russian Federation to be recognized as the great power in a multi-polar hegemony, partly on its roles as protector of Crimea, Abkhazia and South Ossetia, solution provider in Donbas, but also as a great power in the large part of the Black Sea, represents a risk for its stability in the situation if he fails to maintain his domination in this region.

\section{NOTES:}

$1 \mathrm{https} / /$ winstonchurchill.org/resources/speeches/19461963-elder-statesman/the-sinews-of-peace/, accessed on 17.03.2021.

2 https://earning.blogs.nytimes.com/2012/03/05/marc h-5-1946-winston-churchill-warns-of-soviet-iron-curtain/, accessed on 17.03.2021.

$3 \mathrm{http} / / / \mathrm{cpc}-\mathrm{ew} . \mathrm{ro} / \mathrm{pdfs} /$ politica_energetica_a_rusiei.pdf, accessed on 26.05.2021.

4 The Crimean War of 1853 between Russia and the alliance of the Ottoman Empire, the second French Empire, the United Kingdom of Great Britain and Ireland, and the Kingdom of Sardinia.

5 The Polish-Russian war from 1605 to 1618 was represented by a series of military conflicts between the Russian state and the Polish-Lithuanian union, which took advantage of the internal chaos generated by the frequent civil wars unleashed by the interim government of the country, after the tsar's, Fyodor I death in 1598, by transferring power 
from Rurik dynasty (1598) to Romanov dynasty (1513), which was called at the time as the troubled times of Russia.

6 The Great Northern War, of 1700-1721, fought between Swedish troops and those of the coalition of Denmark, Poland and Russia.

7 Napoleon's campaign of 1812, which although it conquered Moscow, in reality became the greatest disaster of the Neapolitan campaigns. The military losses amounted to about 300,000 French, 70,000 Poles, 50,000 Italians, 80,000 Germans and probably 450,000 Russians. The French lost about 200,000 horses and more than 1,000 pieces of artillery.

8 https://www.historia.ro/sectiune/general/articol/ napoleon-wehrmacht-ul-si-capricioasa-vreme-din-rusia, accessed on 18.03.2021.

9 1568-1570, 1676-1681,1686-1700, 1710-1711, 1735$1739,1768-1774,1787-1792,1806-1812,1828-1829,1853-$ 1856, 1877-1878, 1914-1918.

10 The economic potential of the Black Sea region was first discovered by Greek settlers, later by Romans and Byzantines, the economic peak of the region being reached during the commercial expansion of the Italian Genoese and Venetian republics.

11 Initially annexed by Russia through the Peace Treaty of Bucharest of 1812, following the end of the Russo-Turkish War of 1806-1812.

12 http://www.bbc.co.uk/romanian/news/ story/2008/04/080401_bush_bucuresti.shtml, accessed on 18.03.2021.

13 https://georgewbush-whitehouse.archives.gov/ news/releases/2008/04/20080402-2.html, accessed on 18.03.2021.

14 http://www.cpc-ew.ro/pdfs/razboiul_ruso_georgian. pdf, accessed on 18.03.2021.

15 https:/www.youtube.com/watch?v=hQ58Yv6kP44, accessed on 18.03.2021.

16Nagorno-Karabahisadisputedterritory, internationally recognized as part of Azerbaijan, but mostly governed by the unrecognized Artsakh Republic (formerly called the NagornoKarabah Republic (NKR) since the first Nagorno-Karabah War. This is a region without exit to the South Caucasus sea, located in the mountainous area of Karabah, between Lower Karabah and Zangezur, covering the South-Eastern part of the mountains of the Small Caucasus.

17 The Eurasian Economic Union (EEU), established on November 18, 2011, was conceived by Russian President Vladimir Putin as an alternative to the European Union market, but is far from offering its economic benefits. In addition to the 5 states mentioned, in 2019 Serbia also joined.

18 It is an intergovernmental military alliance that was established on May 15, 1992. Uzbekistan joined the organization at the time of its establishment, but left in 1997. It subsequently rejoined in 2006 but withdrew from the CSTO in 2012 .

19 Except for Albania.

20 https:/www.nato.int/nato_static/assets/pdf/pdf_2014 _07/20140716_140716-Factsheet_Russia_en.pdf, accessed on 26.05.2021.

21 Peacekeeping force supported by the US-EgyptianIsraeli Government, established on August 3, 1981.
22 https://www.rand.org/content/dam/rand/pubs/ research_reports/RRA300/RRA357-1/RAND_RRA357-1. pdf, accessed on 19.03.2021, Stephen J. Flanagan \& others, Russia, NATO, and Black Sea Security, Published by the RAND Corporation, Santa Monica, Calif, 2020.

23 https://www.dw.com/ro/ucraina-starea-de-r $\% \mathrm{C} 4 \% 83$ zboi-este-iminent $\% \mathrm{C} 4 \% 83 / \mathrm{a}-46460018$, accessed on 09.03.2021.

24 https://www.dailysabah.com/business/2019/04/09/ turkey-russia-seek-new-ways-to-reach-100b-in-bilateraltrade, accessed on 26.05.2021.

$25 \mathrm{https}$ //eurasianet.org/how-has-conflict-with-russiaaffected-ukraines-trade; and Stephen J. Flanagan \& others, 2020, p. 49.

$26 \mathrm{https}: / /$ www.economica.net/rusia-pregatestesanctiuni-economice-dure-contra-turciei-erdogan-vreaindreptarea-erorilor-facute-de-ambele-parti_110874.html, accessed on 19.03.2021.

27 https://www.europarl.europa.eu/RegData/etudes/ IDAN/2017/578016/EXPO_IDA\%282017\%29578016 EN.pdf, accessed on 26.05.2021.

28 Vesti, „Miroporyadok: Dokumental'nyi fil'm Vladimira Solov'eva [World Order: Documentary by Vladimir Solov'ev]," video, YouTube, 20 December 2015. Ca răspuns la o întrebare referitoare la relațiile dintre Rusia și Occident în ceea ce privește Ucraina și alte probleme, In response to a question about Russia-West relations regarding Ukraine and other issues, Putin replied: "Regarding Ukraine and in general post-Soviet area, I am convinced that the position of our Western partners - European and American - is not focused on protecting the interests of Ukraine. But rather, (their position) is linked to an attempt to interrupt the attempt to recreate the Soviet Union and no one wants to believe that we have no purpose in recreating the Soviet Union. But there is the possibility of uniting (the former Soviet republics) in the modern processes of economic integration (I want to emphasize this word), which would undoubtedly make Russia and Ukraine more competitive in the global economy and which would allow Russia and Ukraine to take their rightful place in the modern system of division of labor in global markets. Even this possibility does not allow our partners to sleep soundly, and I believe that the main task (of the West) is to interrupt this joint effort... Why can the European Union be formed, but not the Eurasian Union?"

29 https://www.rand.org/content/dam/rand/pubs/research _reports/RR1700/RR1793/RAND_RR1793.pdf, accessed on 19.03.2021, Raphael S. Cohen and Andrew Radin, Russia's Hostile Measures in Europe: Understanding the Threat, Santa Monica, CA: RAND Corporation, 2019, p. 67, https:// www.rand.org/pubs/research_reports/RR1793.html

30 https://www.youtube.com/watch?v=w1U4E_QwW pg, accessed on 19.03.2021. Following the activation of the anti-missile system, Putin warned: "Now we are obliged to react in an appropriate manner and if yesterday those parts of Romania's territory did not know what it is like to be in the crosshairs... then today we will have to take certain actions to ensure our security."

31 https://www.telegraph.co.uk/news/2019/04/02/winst on-churchills-naughty-document-written-stalin-go-display/, accessed on 26.05.2021. 
32 https://www.youtube.com/watch?v=sV-8RxtQtcw, accessed on 19.03.2021.

33 Hungary -1956; Czechoslovakia -1968; Afghanistan - 1979; Georgia -2008; Crimea -2014; eastern Ukraine -2014 .

$34 \mathrm{https}: / / \mathrm{www}$. youtube.com/watch?v=6ly2n94izbI, accessed on 19.03.2021.

35 Vladimir Putin, Meeting of the Valdai International Discussion Club, October 22, 2015; Vladimir Putin, Meeting of the Valdai International Discussion Club, October 27, 2016.

36 Stephen J. Flanagan \& others, Russia, NATO, and Black Sea Security, Published by the RAND Corporation, Santa Monica, Calif, 2020, p.72.

\section{REFERENCES}

Benedyczak Jakub, "The Importance of Turkey in Russian Policy", Polski Instytut Spraw Międzynarodowych Bulletin (The Polish Institute of International Affairs), 2020.

Binnendijk Anika, Understanding Russian Black Sea Power Dynamics Through National Security Gaming, Published by the RAND Corporation, Santa Monica, California, 2020.

Brister Paul, "Revisiting the Gordian Knot: Strategic Considerations for Hybrid Warfare", Hybrid Warfare and Transnational Threats: Perspectives for an Era of Persistent Conflict, eds., Paul Brister, William H. Natter, Robert R. Tomes, Council for Emerging National Security Affairs, New York, 2011.

Brusylovska Olga, Dubovyk, Volodymyr, and Koval, Igor (eds.), Black Sea Region in World Policy: Actors, Factors, and Scenarios of the Future, Odesa Mechnikov National University Press, Odesa, 2020.

Brzezinski Zbigniew K, The grand chessboard: American primacy and its geostrategic imperatives / 1928 (reed 1997), Basic Books, A Member of the Perseus Books Group, 1st ed.

Chifu Iulian, Nantoi Oazu, Information war. Typing the model of aggression, Publishing House of the Institute of Political Science and International Relations I.C. Brătianu of the Romanian Academy, Bucharest, 2016.

Diaconescu L., "Island of the World - Moving the World Strategic Center from Heartland to the Indian Ocean", Romanian Journal of Political Geography, 22 (1), 2020.

Dughin Aleksandr, The theory of the multipolar world, People's University, Chișinău, 2014.
Flanagan J. Stephen \& others, Russia, NATO, and Black Sea Security, RAND Corporation, Santa Monica, California, 2020, https://www. rand.org/content/dam/rand/pubs/research_reports/ RRA300/RRA357-1/RAND_RRA357-1.pdf

Freedman Lawrence, The future of war. A history, Litera Publishing House, Bucharest, 2019.

Friedman George, Pressure points. About the future crisis in Europe, Litera Publishing House, Bucharest, 2016.

Hoffman Frank, "The Hybrid Character of Modern Conflict", Hybrid Warfare and Transnational Threats: Perspectives for an Era of Persistent Conflict, eds., Paul Brister, William H. Natter, Robert R. Tomes, Council for Emerging National Security Affairs, New York, 2011.

Ioniță Liviu, "The hybrid dimension of the Russian-Ukrainian conflict", Bulletin of "Carol I" National Defence University no. 3, 2015.

Jacek Reginia-Zacharski, Ukrainian issues in geopolitical thought of the twentieth and twenty first centuries, Wydawnictwo Uniwersytetu Łódzkiego, 2016.

Jenkins Simon, The short history of Europe, from Pericles to Putin, Litera Publishing House, Bucharest, 2019.

Kaplan D. Robert, Ghosts of the Balkans a journey in history, Antet Publishing House, Bucharest, 2008.

Kaplan D. Robert, Revenge of geography. What the map tells us about future conflicts and the fight against destiny, Litera Publishing House, Bucharest, 2015.

Kondratenko Oleg, Ukraine as a Geopolitical Priority of the Russian Federation, National Aviation University, Kiev, Ukraine, 2016.

Mackinder J. Halford, Democratic Ideals And Reality - A Study in the Politics of Reconstruction, NDU Press Defence Classic Edition, 1942.

Maior George, Sergei Konoplyov, Strategic knowledge in the extended area of the Black Sea, RAO Publishing House, Bucharest, 2011.

Marshall Tim, Prisoners of Geography, Litera Publishing House, Bucharest, 2020.

Massie K. Robert, Peter the Great. His life and world, ALL Publishing House, Bucharest, 2015.

Meyers Steven Lee, The New Tsar, Corinth Books, Bucharest, 2016.

Orzechowski Marcin, The Russian Federation's neo-imperial expansionist strategy for the Post- 
Soviet region discussed using the example of the Russo-Georgian conflict of 2008, Reality of Politics. Estimates-Comments-Forecasts 9/2018:30-43, https:// www.ceeol.com/search/article-detail?id=772494

Siudak Michał, "Geopolityczne Wizje Krymu I Ukrainy", Przeglad Geopolityczny 18.

Stancu Mihai-Cristian, "The information war. Case Study: «Rusisia Today» role to cover the mission carried out by the Russian Federation in Eastern Ukraine, between May 2014 and February 2015", Bulletin of "Carol I" National Defence University No. 4/2019.

ÜnalmişAhmet Nafiz, Şafak Oğuz, 2008 RusyaGürcistan Savaşının Vekalet Savaşı Teorisi - The Investigation of 2008 Russia-Georgia War in Terms of the Theory of Proxy War, Açısindan İncelenmesi. Karadeniz Araştırmaları 61/2019:31-41, https:// www.ceeol.com/search/article-detail?id $=782070$

Urban Jakša, "EU Policy Options Towards Post-Soviet De Facto States", Polski Instytut Spraw Międzynarodowych (The Polish Institute of International Affairs), no. 6 (159), October 2017.

Ven Bruusgaard Kristin, Challenges in Russia \& Afghanistan. Crimea and Russia's Strategic Overhaul, Army Strategic Studies Institute, 2014.

Waseem Ahmad Qureshi, The Rise of Hybrid Warfare, 10 NOTRE DAME J. INT'L \& COMP. LAW 173 (2020).

Wojciech Lorenz, Strengthening Deterrence in the Black Sea Region, Polski Instytut Spraw Międzynarodowych (The Polish Institute of International Affairs), 2017.

Wojciech Łysek, Crimea in great powers foreign policy: bordeland-conflict-destabilization, Polskie Towarzystwo Geopolityczne, 2015.

https://winstonchurchill.org/resources/ speeches/1946-1963-elder-statesman/the-sinewsof-peace/ https://learning.blogs.nytimes.com/2012/03/05 /march-5-1946-winston-churchill-warns-of-sovietiron-curtain/

http://cpc-ew.ro/pdfs/politica_energetica_a_ rusiei.pdf

https://www.historia.ro/sectiune/general/artic ol/napoleon-wehrmacht-ul-si-capricioasa-vremedin-rusia

http://www.bbc.co.uk/romanian/news/story/ 2008/04/080401_bush_bucuresti.shtml

https://georgewbush-whitehouse.archives.gov/ news/releases/2008/04/20080402-2.html

http://www.cpc-ew.ro/pdfs/razboiul_ruso_ georgian.pdf

https://www.youtube.com/watch?v=hQ58Y v6kP44

https://www.nato.int/nato_static/assets/pdf/ pdf_2014_07/20140716_140716-Factsheet_ Russia_en.pdf

https://www.dailysabah.com/business/2019 /04/09/turkey-russia-seek-new-ways-to-reach100b-in-bilateral-trade

https://eurasianet.org/how-has-conflict-withrussia-affected-ukraines-trade

https://www.economica.net/rusia-pregatestesanctiuni-economice-dure-contra-turciei-erdoganvrea-indreptarea-erorilor-facute-de-ambele-parti_1 10874.html

https://www.europarl.europa.eu/RegData/etudes/ IDAN/2017/578016/EXPO_IDA\%282017\%29 578016_EN.pdf

https://www.telegraph.co.uk/news/2019/04/ 02/winston-churchills-naughty-document-writtenstalin-go-display/

https://www.dw.com/ro/ucraina-starea-der\%C4\%83zboi-este-iminent $\%$ C4\%83/a-46460018 